\title{
Identification of Alkaloids from Hippeastrum aulicum (Ker Gawl.) Herb. (Amaryllidaceae) Using CGC-MS and Ambient Ionization Mass Spectrometry (PS-MS and LS-MS)
}

\author{
Carliani D. P. B. Bessa, ${ }^{a}$ Jean P. de Andrade, ${ }^{a}$ Renata S. de Oliveira, ${ }^{b}$ Eloilson Domingos, ${ }^{c}$ \\ Heloa Santos, ${ }^{c}$ Wanderson Romão, ${ }^{c}$ Jaume Bastidad ${ }^{d}$ and Warley S. Borges ${ }^{* a}$ \\ ${ }^{a}$ Departamento de Química, Universidade Federal do Espírito Santo, 29075-910 Vitória-ES, Brazil \\ ${ }^{b}$ Departamento de Botânica, Instituto de Biociências, Universidade de São Paulo, \\ 05508-900 São Paulo-SP, Brazil \\ 'Laboratório de Petroleômica e Química Forense, Departamento de Química, \\ Universidade Federal do Espírito Santo, 29075-910 Vitória-ES, Brazil \\ ${ }^{d}$ Grup de Productes Naturals, Departament de Biologia, Sanitat i Medi Ambient, \\ Facultat de Farmàcia, Universitat de Barcelona, 08028 Barcelona, Spain
}

\begin{abstract}
Amaryllidaceae alkaloids are well-known isoquinolines which have demonstrated a wide range of biological activities such as antiviral, anticancer, acetylcholinesterase inhibition, antimalarial, among others. Mass spectrometry (MS) studies based on capillary gas chromatography (CGC), paper spray (PS), and leaf spray (LS) ionization were carried out for alkaloid investigation of the native Brazilian species Hippeastrum aulicum, along with nuclear magnetic resonance (NMR) techniques. Thirty-one alkaloids were identified including the new compound haemanthamine $\mathrm{N}$-oxide. The results from PS- and LS-MS techniques were consistent with those observed in CGC-MS analysis. To the best of our knowledge, it is the first study combining NMR, CGC-MS and the ambient ionization-mass spectrometry (PS- and LS-MS) on Amaryllidaceae plants.
\end{abstract}

Keywords: Amaryllidaceae, Hippeastrum aulicum, CGC-MS, PS-MS/LS-MS, isoquinoline alkaloids

\section{Introduction}

Amaryllidaceae is a well-known family of monocotyledons which are distributed widely over the temperate and warm regions of the world. ${ }^{1}$ Amaryllidaceae plants are able to synthesize a specific group of isoquinoline alkaloids, which have demonstrated remarkable biological activities, such as antitumoral, antiviral, antiparasitic, acetylcholinesterase inhibitory, among others. ${ }^{1}$ The outstanding feature of Amaryllidaceae plants is a consistent presence of a unique group of alkaloids, which have been isolated from all the genera of this family. ${ }^{1}$ The current investigation on Amaryllidaceae alkaloids has focused on hyphenated techniques, which exploit the advantages of both chromatographic and spectral methods. ${ }^{2,3}$ This strategy can be understood as a kind of dereplication process, ${ }^{4}$ which is very

*e-mail: warley.borges@ufes.br attractive in that it avoids labor-intensive chromatographic steps and analysis of worthless components.

Capillary gas chromatography-mass spectrometry (CGC-MS) has become the most successful technique for a dereplication approach to Amaryllidaceae alkaloids since these compounds have shown accurate detection under CGC-MS conditions. The construction of an in-home alkaloidal database based on electron impactmass spectrometry fragmentation (EI-MS) and retention index allows a quick identification of known compounds. ${ }^{5}$ Although most Amaryllidaceae alkaloids are suitable for CGC-MS analysis, even as underivatized compounds, there are exceptions like alkaloids in the form of salts or $N$-oxide, ${ }^{6}$ which therefore require the support of other methodologies for correct identification and/or quantification.

An easier way of generating ions in mass spectrometry was introduced with the new ionization techniques, such as ambient mass spectrometry (or ambient MS). ${ }^{7,8}$ These 
techniques constitute simplified and efficient alternatives for the detection and quantification of analytes directly from their natural environments (the "real world") or when placed on auxiliary surfaces. ${ }^{9}$

An important ambient ionization technique is paper spray (PS) ionization. PS analysis is performed by placing the sample in the middle of a triangular piece of paper, held by a metallic clip attached to a high voltage source that is positioned in front of the inlet orifice of the mass spectrometer (MS). The paper is moistened with a solvent and a high voltage is applied to the paper through the metal clip. Consequently, in the paper tip is formed a spray with charged droplets that go towards the entrance of the MS and are analyzed. ${ }^{9}, 10$

Recently, a variant technique of PS was introduced, the leaf spray (LS). The difference between paper spray and leaf spray is that the latter uses the sample itself (a plant tissue) for generating ions in gaseous phase. Ions can be generated in plant tissue without adding a solvent, ${ }^{11}$ due to the natural juice present in fruit and vegetables. However, mass spectra with more intense signals and an improved signal/noise ratio can be obtained when a solvent is added.

The PS-MS and LS-MS have been applied in chemical identification of natural products present in coffee, ${ }^{12}$ fruits, ${ }^{13}$ extra-virgin olive oils ${ }^{14}$ and herbal teas. ${ }^{15}$ Furthermore, LS-MS has also demonstrated excellent sensitivity for the direct identification of chemical species on the surface of leaves of plants such as Populus deltoids, Populus grandidentata, ${ }^{11}$ Hibiscus moscheutos, Hibiscus syriacus ${ }^{16}$ and Illicium anisatum. ${ }^{17}$

In the present work, indigenous Brazilian Hippeastrum aulicum was submitted to a classical phytochemical procedure assisted by CGC-MS, PS-MS and LS-MS. Thirty-one compounds were identified, including the new compound haemanthamine $\mathrm{N}$-oxide, which was completely characterized by mono (1D) and bidimensional (2D) nuclear magnetic resonance (NMR) experiments. The results obtained via CGC-MS were compared with ambient mass spectrometry techniques (PS-MS and LS-MS).

\section{Experimental}

\section{General experimental procedures}

Column chromatography (CC) and vacuum liquid chromatography (VLC) were carried out using silica gel 60 (70-230 mesh, Merck) and silica gel 60 ACC (6-35 $\mu \mathrm{m}$, Chromagel-SDS), respectively. For thin layer chromatography (TLC), commercial plates with silica gel $\mathrm{F}_{254}$ as the stationary phase and dimensions of $20 \mathrm{~cm} \times 20 \mathrm{~cm} \times 0.20 \mathrm{~mm}$ and $20 \mathrm{~cm} \times 20 \mathrm{~cm} \times 0.25 \mathrm{~mm}$ were used for analytical and semi-preparative TLC (SPTLC), respectively. High performance liquid chromatography (HPLC) was performed on an Agilent G1311C-1260 quaternary pump coupled to a UV-Vis diode array (DAD), model G1315D-1260, using the semi-preparative column Zorbax RX-Sil $(9.4 \times 250 \mathrm{~mm}, 5 \mu \mathrm{m})$ and HPLC grade solvents. NMR spectra (nuclear magnetic resonance) were recovered on a Varian $400 \mathrm{MHz}$ instrument using deuterated chloroform $\left(\mathrm{CDCl}_{3}\right)$ or deuterated methanol $\left(\mathrm{CD}_{3} \mathrm{OD}\right)$ as solvents and tetramethylsilane (TMS) as the internal standard. The CGC-MS spectra (capillary gas chromatography-mass spectrometry) were obtained on a GC-17A Shimadzu CG-MS QP 5000 operating in the EI mode at $70 \mathrm{eV}$ using a DB5 MS column $(30 \mathrm{~m} \times 0.25 \mathrm{~mm} \times 0.25 \mu \mathrm{m})$. The temperature program was as follows: $100-180^{\circ} \mathrm{C}$ at $15^{\circ} \mathrm{C} \mathrm{min}^{-1}, 1 \mathrm{~min}$ hold at $180{ }^{\circ} \mathrm{C}$ and $180-300{ }^{\circ} \mathrm{C}$ at $5^{\circ} \mathrm{C} \mathrm{min}^{-1}$ and $10 \mathrm{~min}$ hold at $300^{\circ} \mathrm{C}$. The injector temperature was $280{ }^{\circ} \mathrm{C}$. The flow rate of carrier gas (helium) was $0.8 \mathrm{~mL} \mathrm{~min}^{-1}$, and the split ratio was 1:20. HRESIMS (high-resolution electrospray ionization mass spectrometry) was performed on 9.4 T FT-ICRMS (Solarix) by direct injection of the compound dissolved in methanol (MeOH). A Jasco-J-810 Spectrophotometer (Easton, MD, USA) was used to run CD (circular dichroism) spectra, all recorded in $\mathrm{MeOH}$. Infrared (IR) spectrum was recorded on a PerkinElmer Spectrum 400 FT-IR/FT-NIR Spectrometer. UV (ultraviolet) spectrum was obtained on a UV-PerkinElmer, Lambda 45, UV-Vis.

Acetone $\left(\mathrm{Me}_{2} \mathrm{CO}\right)$, ammonia $\left(\mathrm{NH}_{3}\right)$, ammonium hydroxide $\left(\mathrm{NH}_{4} \mathrm{OH}\right)$, 1-butanol $(n$ - $\mathrm{BuOH})$, dichloromethane $\left(\mathrm{CH}_{2} \mathrm{Cl}_{2}\right), n$-hexane (n-Hex), ethyl acetate (EtOAc) and sulphuric acid $\left(\mathrm{H}_{2} \mathrm{SO}_{4}\right)$ used for the extraction and isolation procedures were of analytical grade.

\section{Plant material}

Approximately $1.7 \mathrm{~kg}$ of fresh bulbs and $1.0 \mathrm{~kg}$ of fresh leaves of Hippeastrum aulicum (Ker Gawl.) Herb. were collected in Biritiba-Mirim City of São Paulo State, in September 2013. A voucher specimen was deposited in the Herbarium UEC (Campinas-SP, Brazil), under the reference number 114. The species was identified by Dr Renata S. de Oliveira. A new specimen was collected at the same location in February 2016 and again identified as H. aulicum (Ker Gawl.) Herb. by Dr Renata S. de Oliveira. This specimen was used for ambient MS analysis.

\section{Extract procedure}

Fresh bulbs and leaves from $H$. aulicum were crushed and extracted with $\mathrm{MeOH}$ and the mixture was immediately 
filtered and the solvent evaporated under reduced pressure. The plant material was then twice extracted with $\mathrm{MeOH}$ (48 hours each), filtered and the solvent evaporated under reduced pressure. The remaining crude extract was finally combined.

\section{Extraction and isolation procedures}

\section{Leaves}

The leaf crude extract was acidified with $\mathrm{H}_{2} \mathrm{SO}_{4}(2 \%)$ up to $\mathrm{pH} 2$ and extracted with $n$-Hex $(9 \times 200 \mathrm{~mL})$ to remove neutral material. The aqueous phase was basified with $\mathrm{NH}_{4} \mathrm{OH}$ (25\%) up to $\mathrm{pH} 10$ and extracted with $n$-Hex $(5 \times 200 \mathrm{~mL})$ yielding the extract IA $(166.5 \mathrm{mg})$, followed by the extraction with EtOAc $(15 \times 200 \mathrm{~mL})$ affording extract IIA $(897.2 \mathrm{mg})$, and finally extracted with the mixture of EtOAc: $\mathrm{MeOH}(3: 1,3 \times 200 \mathrm{~mL})$ providing the extract IIIA (1.56 g).

The extract IA was chromatographed by CC, starting with a mixture of EtOAc: $n$-Hex (9:1), gradually increasing the polarity up to $100 \%$ EtOAc and finally increasing the $\mathrm{MeOH}$ percentage in the mixture up to a ratio of EtOAc:MeOH (1:1). 320 fractions (5 mL each) were collected and after analytical TLC were grouped by similarity in six fractions. Fraction 5 was resuspended in $\mathrm{MeOH}$, and haemanthamine (16) $(5.0 \mathrm{mg})$ precipitated spontaneously. Fraction 6 was purified by SPTLC ( $n$-Hex:EtOAc: $\mathrm{Me}_{2} \mathrm{CO}: \mathrm{MeOH}$ :isopropanol, 5:2:2:1:2, in $\mathrm{NH}_{3}$ atmosphere) and allowed the isolation of albomaculine (29) (5.9 mg).

A CC column (EtOAc:MeOH, 49:1) was performed to purify the components of the extract IIA, in which 800 fractions (4 mL each) were collected and combined according to their TLC profile, which afforded 11 fractions. Fraction $9(650.5 \mathrm{mg})$ was resuspended in $\mathrm{MeOH}$ and haemanthamine (16) (228.2 mg) precipitated spontaneously. The supernatant was subjected to CC, starting with EtOAc:MeOH (23:2) and increasing solvent polarity with $\mathrm{MeOH}$ up to $1: 1$, which allowed the collection of 342 fractions ( $4 \mathrm{~mL}$ each). Fractions were compared by analytical TLC (plates were revealed with Dragendorff's reagent and UV light at $254 \mathrm{~nm}$ ) and combined according to their similarities, obtaining 10 subfractions. From subfraction 9.7 (320.5 mg, viscous material), $66.0 \mathrm{mg}$ of haemanthamine (16) precipitated spontaneously. The supernatant from subfraction 9.7 was purified by CC starting with EtOAc:MeOH (9:1), gradually increasing the $\mathrm{MeOH}$ percentage up to EtOAc: $\mathrm{MeOH}(1: 1)$ and affording 634 fractions ( $3 \mathrm{~mL}$ each). After analytical TLC analysis, fractions were again combined by similarity, yielding 12 subfractions. Sample 9.8.7 was purified by
SPTLC (EtOAc: $\mathrm{CH}_{2} \mathrm{Cl}_{2}: \mathrm{Me}_{2} \mathrm{CO}: \mathrm{MeOH}: n-\mathrm{Hex}, 2: 2: 2: 1: 1$, along with drops of $\mathrm{NH}_{4} \mathrm{OH}$, in $\mathrm{NH}_{3}$ atmosphere) allowing the purification of the alkaloids haemanthidine (22) and 6-epihaemanthidine (23) (16.5 mg).

Fractions $10(33.9 \mathrm{mg})$ and $11(34.5 \mathrm{mg})$ were purified by SPTLC ( $n$-Hex:EtOAc:Me ${ }_{2} \mathrm{CO}: \mathrm{MeOH}: n$-BuOH, 4:3:3:2:1, in $\mathrm{NH}_{3}$ atmosphere). Haemanthamine $\mathrm{N}$-oxide (1) $(10.0 \mathrm{mg})$ and 7-methoxy-O-methyllycorenine $(\mathbf{1 2})(5.7 \mathrm{mg})$ were obtained from fraction 10 and-compound $\mathbf{1 2}(6.7 \mathrm{mg})$ was again obtained from fraction 11.

The extract IIIA showed a negligible alkaloid content by CGC-MS and analytical TLC analysis.

\section{Bulbs}

The bulb extract was submitted to the same acid-base extraction as outlined previously. The $n$-Hex extract (IB) afforded $506.7 \mathrm{mg}$, while the EtOAc extract (IIB) yielded $2.65 \mathrm{~g}$. Finally, $2.06 \mathrm{~g}$ was provided by the EtOAc:MeOH (3:1) extract (IIIB).

The extract IB was subjected to $\mathrm{CC}$ eluting, firstly with a mixture of EtOAc: $\mathrm{MeOH}: \mathrm{CH}_{2} \mathrm{Cl}_{2}$ (3:1:1), along with drops of the $\mathrm{NH}_{4} \mathrm{OH}$. The system polarity was gradually increased, enriching the mixture with $\mathrm{MeOH}$ and decreasing the amount of EtOAc to $50 \%$ of $\mathrm{MeOH}$ in the mixture. Approximately 770 fractions of $5 \mathrm{~mL}$ each were collected. These fractions were analyzed by TLC and then combined according to their alkaloidal profile under UV $\lambda 254$ light and Dragendorff's reactive spots, affording 18 fractions. Fraction $9(60.0 \mathrm{mg})$ was purified by SPTLC $\left(\mathrm{CH}_{2} \mathrm{Cl}_{2}\right.$ :EtOAc: $\mathrm{Me}_{2} \mathrm{CO}: n$-Hex:MeOH, 2:2:1.5:3:1, along with drops of $\mathrm{NH}_{4} \mathrm{OH}$, in $\mathrm{NH}_{3}$ atmosphere) and alkaloids haemanthamine (16) (6.5 mg), albomacuine (29) $(3.5 \mathrm{mg})$ and 7-methoxy- $O$-methyllycorenine $(\mathbf{1 2})(8.0 \mathrm{mg})$ were isolated. The alkaloid aulicine $(\mathbf{1 5})(48.0 \mathrm{mg})$ precipitated from fraction 11.

After resuspension of the extract IIB in $\mathrm{MeOH}$, lycorine (25) (160.7 mg) precipitated spontaneously. The supernatant $(1.94 \mathrm{~g})$ was then subjected to a VLC column $(4.4 \times 7.0 \mathrm{~cm})$, starting with $100 \%$ of $n$-Hex, gradually enriching with EtOAc (0-100\%) and finally with $\mathrm{MeOH}$ (0-50\%). A total of 216 fractions ( $50 \mathrm{~mL}$ each) was obtained and combined according to their alkaloid profile by TLC (UV 256 and Dragendorff's reactive spots), affording 12 fractions. The alkaloid trisphaeridine (3) (1.5 mg) was isolated by HPLC from fraction 4 using a normal phase column $(9.4 \times 250 \mathrm{~mm})$ and EtOAc: $n$-Hex $(4: 1)$ mixture as a mobile phase under a flow rate of $0.75 \mathrm{~mL} \mathrm{~min}{ }^{-1}$. In fraction $12(1.17 \mathrm{~g})$ the alkaloid haemanthamine $(\mathbf{1 6})(251.6 \mathrm{mg})$ precipitated after resuspension in $\mathrm{MeOH}$. The supernatant was purified by $\mathrm{CC}$ and the system elution started with a mixture of EtOAc: $\mathrm{CH}_{2} \mathrm{Cl}_{2}: \mathrm{Me}_{2} \mathrm{CO}: \mathrm{MeOH}: n-\mathrm{Hex}$ 
(2:2:1:1:1), the system polarity being increased by adding $\mathrm{MeOH}$ (up to the ratio 2:2:1:5:1). 944 fractions of $4 \mathrm{~mL}$ each were obtained. The fractions were combined according to their alkaloid profile by TLC using UV ( $\lambda$ 256) and Dragendorff's reagent stain, resulting in 11 subfractions. SPTLC (EtOAc: $\mathrm{CH}_{2} \mathrm{Cl}_{2}: \mathrm{Me}_{2} \mathrm{CO}: \mathrm{MeOH}: n-\mathrm{Hex}, 2: 2: 1: 1: 1$, along with drops of the $\mathrm{NH}_{4} \mathrm{OH}$, in $\mathrm{NH}_{3}$ atmosphere) was performed to purify subfraction 13.6, and the alkaloid galanthine (21) (3.6 mg) was isolated. Subfraction 13.7 was identified as the alkaloid haemanthamine (16) $(49.0 \mathrm{mg})$. After resuspension of subfraction 13.8 in $\mathrm{MeOH}$, haemanthamine (16) (253.0 mg) precipitated spontaneously. Subfraction 13.9 was purified by SPTLC (EtOAc: $\mathrm{CH}_{2} \mathrm{Cl}_{2}: \mathrm{Me}_{2} \mathrm{CO}: \mathrm{MeOH}: n$-Hex, 2:2:1:1:1, along with drops of the $\mathrm{NH}_{4} \mathrm{OH}$, in $\mathrm{NH}_{3}$ atmosphere) resulting in the isolation of the isomers haemanthidine (22) and 6-epihaemanthidine (23) $(3.5 \mathrm{mg})$ and alkaloid norpluviine (14) $(1.5 \mathrm{mg})$.

Like extract IIIA, extract IIIB showed a negligible alkaloid content by CGC-MS and analytical TLC analysis.

Haemanthamine $\mathrm{N}$-oxide (1)

Amorphous solid; CD $[\Theta]_{\lambda}^{20}:[\Theta]_{245}-5224$, $[\Theta]_{294}+2788$; UV (MeOH) $\lambda_{\max } / \mathrm{nm}(\varepsilon) 237$ (1692), 292
(1884); IR $\left(\mathrm{CHCl}_{3}\right) v_{\max } / \mathrm{cm}^{-1} 3361,2926,1640,1487$, $1247,1037,750 ;{ }^{1} \mathrm{H}$ NMR $\left(400 \mathrm{MHz}, \mathrm{CDCl}_{3}\right)$ and ${ }^{13} \mathrm{C} \mathrm{NMR}$ $\left(100 \mathrm{MHz}, \mathrm{CDCl}_{3}\right)$ see Table 1; HRESIMS of $[\mathrm{M}+\mathrm{H}]^{+}$ $\mathrm{m} / \mathrm{z} 318.13362$ (calculated for $\mathrm{C}_{17} \mathrm{H}_{20} \mathrm{NO}_{5}: 318.13360$ ).

\section{Identification of alkaloids by CGC-MS}

The alkaloids were identified by comparing their CGCMS spectra and Kovats retention indices (RI) with our library database. This library has been regularly updated with alkaloids isolated and unequivocally identified via physical and spectroscopic methods..$^{18}$ NMR data for the known alkaloids described herein closely matched those reported elsewhere. ${ }^{18-26}$ Mass spectra were deconvoluted using AMDIS 2.64 software (NIST) (WA, USA) and RIs recorded using a standard $n$-hydrocarbon calibration mixture (C9-C36). The proportion of individual components in the alkaloid fractions are expressed as a percentage of total alkaloid content. CGC-MS peak areas are dependent on the concentration of the injected alkaloid as well as the intensity of its mass spectral fragmentation. Although the data given in Table 2 are not representative of a validated alkaloid quantification method, they can be used for relative comparison purposes.

Table 1. ${ }^{1} \mathrm{H}$ NMR, COSY, NOESY, HSQC and HMBC data of haemanthamine $N$-oxide (1) (400 MHz, $\left.\mathrm{CD}_{3} \mathrm{OD}\right)$

\begin{tabular}{|c|c|c|c|c|c|}
\hline Position & $\delta_{\mathrm{H}}(J$ in $\mathrm{Hz})$ & COSY & NOESY & $\mathrm{HSQC} /{ }^{13} \mathrm{C}$ & HMBC \\
\hline 1 & $6.36 \mathrm{br} \mathrm{s}$ & & $\mathrm{H}-10$ & $126.8 \mathrm{~d}$ & C-3, C-4a, C-10b \\
\hline 2 & $6.36 \mathrm{br} \mathrm{s}$ & $\mathrm{H}-3, \mathrm{H}-4 \beta$ & $\mathrm{H}-3$ & $131.5 \mathrm{~d}$ & $\mathrm{C}-3, \mathrm{C}-10 \mathrm{~b}$ \\
\hline 3 & 4.02 br s & $H-2, H-4 \alpha, H-4 \beta$ & $\begin{array}{c}\mathrm{H}-2,3-\mathrm{OMe}, \mathrm{H}-4 \alpha, \\
\mathrm{H}-4 \beta\end{array}$ & $72.9 \mathrm{~d}$ & $\mathrm{C}-1, \mathrm{C}-2$ \\
\hline $4 \alpha$ & 2.36 ddd $(13.6,13.2,4.4)$ & $\mathrm{H}-3, \mathrm{H}-4 \mathrm{a}, \mathrm{H}-4 \beta$ & $\mathrm{H}-3, \mathrm{H}-12$ exo, $\mathrm{H}-4 \beta$ & $24.7 \mathrm{t}$ & C-4a \\
\hline $4 \beta$ & $2.75 \operatorname{ddd}(13.6,4.0,1.6)$ & H-2, H-3, H-4a, H- $4 \alpha$ & H-3, H-4a, H-4 $\alpha$ & & $C-2, C-3, C-4 a, C-10 b$ \\
\hline $4 a$ & $3.74 \mathrm{dd}(13.2,3.6)$ & H- $4 \alpha, \mathrm{H}-4 \beta$ & $\mathrm{H}-4 \beta, \mathrm{H}-6 \beta$ & $75.2 \mathrm{~d}$ & C-11 \\
\hline $6 \alpha$ & $4.68 \mathrm{~d}(15.4)$ & $\mathrm{H}-7$ & $\mathrm{H}-7, \mathrm{H}-12$ endo & $75.4 \mathrm{t}$ & C-4a, C-6a, C-7, C-10a \\
\hline $6 \beta$ & $4.75 \mathrm{~d}(15.4)$ & H-7, H-12exo & $\mathrm{H}-4 \mathrm{a}, \mathrm{H}-7$ & & C-6a, C-7, C-10a, C-12 \\
\hline $6 a$ & & & & $122.5 \mathrm{~s}$ & \\
\hline 7 & $6.68 \mathrm{~s}$ & H- $6 \alpha, H-6 \beta$ & H- $6 \alpha, H-6 \beta$ & $107.3 \mathrm{~d}$ & C-6, C-9, C-10a \\
\hline 8 & & & & $148.9 \mathrm{~s}$ & \\
\hline 9 & & & & $149.6 \mathrm{~s}$ & \\
\hline 10 & $6.98 \mathrm{~s}$ & & $\mathrm{H}-1$ & $104.5 \mathrm{~d}$ & C-6a, C-8, C-10b \\
\hline $10 \mathrm{a}$ & & & & $133.5 \mathrm{~s}$ & \\
\hline $10 \mathrm{~b}$ & & & & $53.7 \mathrm{~s}$ & \\
\hline 11 endo & 3.94 br dd $(7.2,3.6)$ & $\mathrm{H}-12$ endo, $\mathrm{H}-12$ exo & $\mathrm{H}-12$ endo & $77.3 \mathrm{~d}$ & \\
\hline 12 endo & $4.37 \mathrm{dd}(13.6,7.2)$ & $\mathrm{H}-11$ endo, $\mathrm{H}-12$ exo & $\begin{array}{c}\mathrm{H}-6 \alpha, \mathrm{H}-11 \text { endo, } \\
\mathrm{H}-12 \text { exo }\end{array}$ & $76.9 \mathrm{t}$ & C- $4 a, C-6, C-10 b$ \\
\hline $12 e x o$ & $3.71-3.66 \mathrm{~m}$ & $\begin{array}{l}\mathrm{H}-6 \beta, \mathrm{H}-11 \text { endo, } \\
\mathrm{H}-12 \text { endo }\end{array}$ & $\mathrm{H}-4 \alpha, \mathrm{H}-12 \mathrm{endo}$ & & \\
\hline 3-OMe & $3.39 \mathrm{~s}$ & & $\mathrm{H}-3$ & $57.0 \mathrm{q}$ & C-3 \\
\hline $\mathrm{OCH}_{2} \mathrm{O}$ & $5.97 \mathrm{~s}$ & & & $103.0 \mathrm{t}$ & C-8, C-9 \\
\hline
\end{tabular}

COSY: correlation spectroscopy; NOESY: nuclear Overhauser effect spectroscopy; HSQC: heteronuclear single quantum coherence; HMBC: heteronuclear multiple bond correlation. 
Table 2. CGC-MS data for H. aulicum. Values are expressed as a relative percentage of total ion current (TIC)

\begin{tabular}{|c|c|c|c|c|c|c|c|}
\hline \multirow{2}{*}{ Alkaloid } & \multirow{2}{*}{ RI } & \multicolumn{2}{|c|}{ Bulbs $/ \%$} & \multicolumn{2}{|c|}{ Leaves $^{\mathrm{b}} / \%$} & \multirow{2}{*}{$\mathrm{M}^{+}$} & \multirow{2}{*}{ MS } \\
\hline & & IB & IIB & IA & IIA & & \\
\hline Ismine (2) & 2280 & - & $\operatorname{tr}^{\mathrm{d}}$ & - & $\operatorname{tr}^{\mathrm{d}}$ & $257(35)$ & 238(100), 211(6), 196(8), 168(6), 154(3), 106(4), \\
\hline Trisphaeridine (3) & 2282 & 0.13 & 0.47 & 0.10 & 0.54 & $223(100)$ & $\begin{array}{c}222(38), 167(8), 165(9), 164(14), 138(20), 137(9), \\
111(13)\end{array}$ \\
\hline Galanthamine (4) & 2395 & 6.43 & 6.11 & 0.34 & $\operatorname{tr}^{\mathrm{d}}$ & $287(83)$ & $\begin{array}{c}286(100), 270(13), 244(24), 230(12), 216(33) \\
174(27), 115(12)\end{array}$ \\
\hline Lycoramine (5) & 2420 & $\operatorname{tr}^{\mathrm{d}}$ & $\operatorname{tr}^{\mathrm{d}}$ & - & - & $289(62)$ & $\begin{array}{c}288(100), 232(8), 202(14), 187(14), 159(9) \\
115(19)\end{array}$ \\
\hline Buphanisine (6) & 2424 & $\operatorname{tr}^{\mathrm{d}}$ & - & - & - & $285(100)$ & $\begin{array}{c}270(33), 254(34), 215(85), 201(24), 172(19), \\
157(21), 115(33)\end{array}$ \\
\hline Vitattine (7) & 2472 & - & 0.55 & - & - & 271(100) & $\begin{array}{c}228(25), 199(95), 187(85), 173(28), 128(32) \\
115(33), 56(22)\end{array}$ \\
\hline Narwedine (8) & 2483 & 0.22 & $\operatorname{tr}^{\mathrm{d}}$ & $\operatorname{tr}^{\mathrm{d}}$ & - & $285(84)$ & $\begin{array}{c}284(100), 242(18), 216(20), 199(18), 174(31), \\
128(16), 115(16)\end{array}$ \\
\hline$O$-Methyllycorenine (9) & 2492 & 0.65 & - & - & - & $331(<1)$ & $\begin{array}{c}300(3), 191(8), 147(1), 110(8), 109(100), 94(3) \\
77(1)\end{array}$ \\
\hline Nerinine (10) & 2509 & - & 0.86 & - & - & $347(<1)$ & $\begin{array}{c}222(1), 207(2), 179(1), 164(1), 110(8), 109(100), \\
108(18), 94(2)\end{array}$ \\
\hline 8-O-Demethylmaritidine (11) & 2510 & - & 1.27 & - & 0.83 & $273(100)$ & $\begin{array}{c}256(22), 230(20), 201(83), 189(42), 174(22) \\
128(23), 115(24)\end{array}$ \\
\hline 7-Methoxy- $O$-methyllycorenine (12) & 2538 & 17.71 & - & - & $\operatorname{tr}^{\mathrm{d}}$ & $361(<1)$ & $\begin{array}{c}330(8), 221(10), 191(2), 110(8), 109(100) \\
108(15), 94(2), 83(2)\end{array}$ \\
\hline 11-Oxohaemanthamine (13) & 2585 & - & $\operatorname{tr}^{\mathrm{d}}$ & - & $\operatorname{tr}^{\mathrm{d}}$ & $299(<1)$ & $\begin{array}{c}271(100), 270(37), 240(10), 238(10), 211(23), \\
181(77), 152(20)\end{array}$ \\
\hline Norpluviine (14) & 2596 & - & $\operatorname{tr}^{\mathrm{d}}$ & - & - & 273(68) & $\begin{array}{c}272(41), 254(45), 229(45), 228(100), 214(13), \\
186(10), 147(8), 91(8), 77(12)\end{array}$ \\
\hline Aulicine (15) & 2607 & 44.24 & 12.06 & 60.62 & 3.17 & $319(100)$ & $\begin{array}{c}304(19), 288(37), 246(18), 233(73), 218(19) \\
206(26), 163(7)\end{array}$ \\
\hline Haemanthamine (16) & 2641 & 14.66 & 71.09 & 20.60 & 92.0 & 301(14) & $\begin{array}{c}272(100), 257(10), 240(16), 181(21), 214(12), \\
211(14), 128(8)\end{array}$ \\
\hline Crinamine (17) & 2648 & - & - & 0.27 & - & $301(<1)$ & $\begin{array}{c}\text { 272(100), 242(10), 211(17), 181(23), 153(14), } \\
128(18), 115(16), 77(6)\end{array}$ \\
\hline Tazettine (18)/Pretazettine (19) ${ }^{\mathrm{c}}$ & 2653 & 0.44 & 1.57 & $\operatorname{tr}^{\mathrm{d}}$ & 0.61 & $331(31)$ & $\begin{array}{c}316(15), 298(23), 247(100), 230(12), 201(15), \\
181(11), 152(7)\end{array}$ \\
\hline Hamayne (20) & 2699 & - & - & - & 0.19 & $287(3)$ & $\begin{array}{c}258(100), 242(6), 211(12), 186(17), 181(11) \\
153(10), 128(19)\end{array}$ \\
\hline Galanthine (21) & 2709 & - & 0.41 & - & 0.33 & $317(22)$ & $\begin{array}{c}316(15), 298(10), 268(18), 243(96), 242(100), \\
228(8)\end{array}$ \\
\hline Haemanthidine (22)/6-Epihaemanthidine (23) & 2716 & - & $\operatorname{tr}^{\mathrm{d}}$ & - & $\operatorname{tr}^{\mathrm{d}}$ & $317(59)$ & $\begin{array}{c}284(52), 233(48), 211(45), 201(80), 199(70) \\
181(69), 173(71), 115(10), 56(71)\end{array}$ \\
\hline 11-Hydroxyvittatine (24) & 2728 & - & 0.60 & - & 0.40 & $287(5)$ & $\begin{array}{c}258(100), 211(15), 186(20), 181(23), 153(13), \\
128(24), 115(23)\end{array}$ \\
\hline Lycorine (25) & 2746 & - & 0.71 & - & $\operatorname{tr}^{\mathrm{d}}$ & $287(31)$ & $\begin{array}{c}286(19), 268(24), 250(15), 227(79), 226(100), \\
211(7), 147(15)\end{array}$ \\
\hline Incartine (26) & 2756 & - & 1.24 & $\operatorname{tr}^{\mathrm{d}}$ & $\operatorname{tr}^{\mathrm{d}}$ & $333(42)$ & $\begin{array}{c}332(100), 315(25), 259(73), 258(97), 244(17), \\
242(6), 214(9), 172(45)\end{array}$ \\
\hline Homolycorine (27) & 2765 & 6.52 & 1.68 & $\operatorname{tr}^{\mathrm{d}}$ & 1.82 & $315(<1)$ & $\begin{array}{c}206(<1), 178(2), 109(100), 150(1), 108(22) \\
94(3), 82(3)\end{array}$ \\
\hline 3-Epimacronine (28) & 2811 & $\operatorname{tr}^{\mathrm{d}}$ & 0.25 & - & $\operatorname{tr}^{\mathrm{d}}$ & $329(27)$ & $\begin{array}{c}314(23), 245(100), 225(14), 201(83), 139(16), \\
70(18)\end{array}$ \\
\hline Albomaculine (29) & 2815 & 8.93 & 1.08 & 3.10 & - & $345(<1)$ & $\begin{array}{c}\text { 221(1), 193(1), 165(1), 110(10), 109(100), } \\
108(25), 94(2), 82(3)\end{array}$ \\
\hline 8-O-Demethylhomolycorine (30) & 2841 & - & - & 14.94 & - & $301(<1)$ & 195(0.5), 164(2), 109(100), 108(25), 94(3), 82(3) \\
\hline $2 \alpha$-Methoxyhomolycorine $(\mathbf{3 1})^{\mathrm{e}}$ & 2870 & - & - & $\operatorname{tr}^{\mathrm{d}}$ & - & $345(<1)$ & $\begin{array}{c}206(<1), 178(2), 150(1), 139(100), 124(64) \\
96(5), 94(5), 81(3)\end{array}$ \\
\hline
\end{tabular}


PS-MS and LS-MS

For LS-MS analysis, freshly collected leaves and bulbs of H. aulicum were cut into a triangle (base and height of $1 \mathrm{~cm}$ each) and held by a metal clip at a distance of 5-7 $\mathrm{mm}$ from the mass spectrometer inlet (Figure 1a). ${ }^{9}$ Approximately $10 \mu \mathrm{L}$ of $\mathrm{MeOH}$ (HPLC grade, JTBaker) and a high voltage $(3 \mathrm{kV})$ supplied by the mass spectrometer were applied to the leaf or bulb to generate the LS mass spectra.

For PS-MS analysis, extracts of bulbs and leaves were dissolved in $\mathrm{MeOH}$ at $2 \mathrm{mg} \mathrm{mL}^{-1}$. Then, $10 \mu \mathrm{L}$ of solution was applied on the surface of a triangular paper (Whatman Grade 1, GE Healthcare $)^{27,28}$ with base and height of $1 \mathrm{~cm}$ each . The triangular paper was fixed with a metal clip, connected to $0.5 \mathrm{~mm}$ wire linked to the mass spectrometer (Figure $1 \mathrm{~b}$ ). Then, $20 \mu \mathrm{L}$ of $\mathrm{MeOH}$ was applied with a high voltage $(3 \mathrm{kV})$ to the triangular paper to generate the PS mass spectra.

LS and PS-MS experiments were performed in positive ion mode (LS(+) and PS(+)) using a Fourier transform ion cyclotron resonance mass spectrometer (FT-ICR MS, model 9.4 T Solarix, Bruker Daltonics Bremen). ${ }^{27,29}$ Ion time accumulation was $0.010 \mathrm{~s}$. LS(+) and PS(+)-FT-ICR mass spectra were acquired by accumulating 32 scans of timedomain transient signals in 16 mega-point time-domain data sets. All mass spectra were externally calibrated using NaTFA ( $\mathrm{m} / \mathrm{z}$ from 200 to 1200$)$. A resolving power, $m / \Delta m_{50 \%}=78000$ (in which $\Delta m_{50 \%}$ is the full peak width at the half-maximum peak height of $\mathrm{m} / \mathrm{z}, 300$ ) and a mass accuracy of $<2 \mathrm{ppm}$ provided the unambiguous molecular formula assignments for singly charged molecular ions. The proposed structures for each formula were assigned using the chemspider (www.chemspider.com) database. The degree of unsaturation for each molecule can be deduced directly from its double bond equivalent (DBE) value according to equation DBE $=\mathrm{c}-\mathrm{h} / 2+\mathrm{n} / 2+1$, where $\mathrm{c}$, $\mathrm{h}$, and $\mathrm{n}$ are the numbers of carbon, hydrogen, and nitrogen atoms, respectively, in the molecular formula. ${ }^{29}$

(a) LS(+)-FT-ICR MS

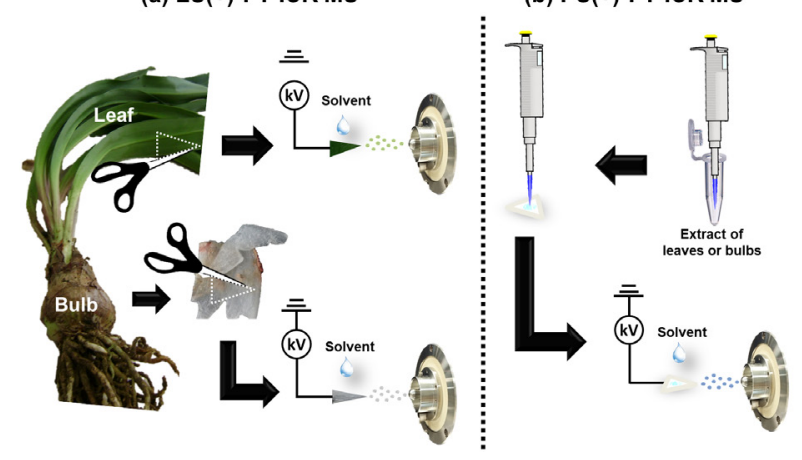

Figure 1. Scheme of (a) LS(+)-FT-ICR MS and (b) PS(+)-FT-ICR MS analyzes.

\section{Results and Discussion}

\section{Alkaloid comparison}

The phytochemical procedure assisted by MS and NMR approaches identified thirty-one compounds in $\mathrm{H}$. aulicum (Figure 2 and Table 2). Thirteen alkaloids are reported here for the first time in $H$. aulicum, although some chemical similarities with previous studies have also been found. ${ }^{18,30}$ The H. aulicum studied here, from Biritiba-Mirim City (São Paulo, Brazil), displayed aulicine (15), haemanthamine (16), and lycorine (25) as the main compounds, as does H. aulicum from Cunha City (São Paulo, Brazil).$^{18}$ Both Brazilian cities are relatively close, which may explain the presence of the same major components. Lycorine (25) was found to be one of the main alkaloids (see Experimental section) even though its low solubility in $\mathrm{MeOH}^{31}$ covered the correct relative quantification by CGC-MS (Table 2). A former $H$. aulicum investigation ${ }^{30}$ also revealed alkaloids such as norpluviine (14) and galanthine (21), which were observed in the present work. No information about the collection of the plant species in this previous study is available. In contrast, while ambelline, anhydrolycorine, chlidanthine, montanine, narcissidine and pseudolycorine have been previously reported, ${ }^{18,30}$ they were not found in this work. Notably, the identification of the alkaloids incartine (26) and buphanisine (6), which are uncommon in the Hippeastrum genus, is reported here for the first time in H. aulicum. ${ }^{32}$

\section{CGC-MS dereplication}

The CGC-MS results are shown in Table 2. The specific EI-MS fragmentation mechanisms for the distinct skeleton types together with retention indices are the key for alkaloid identification in Amaryllidaceae research. Concerning the skeleton types found in $H$. aulicum, the EI mass fragmentation of homolycorine-type alkaloid $\Delta^{3,4}$-derivatives features a dominant retro-Diels Alder process and cleavage of ring $\mathrm{C}$, yielding a very abundant ion peak characterized by the pyrrolidine ring $(\mathrm{m} / \mathrm{z}, 109){ }^{33}$ Consequently, the alkaloids 9, 10, 12, 27, 29 and 30 show the base peak at $\mathrm{m} / \mathrm{z} 109(100 \%)$, with all remaining ion peaks displaying less than $10 \%$ of abundance. Otherwise, alkaloid $\mathbf{3 1}$ possesses a methoxyl group at C-2 and so displays the base peak at $\mathrm{m} / \mathrm{z} 139$, which is in agreement with the pyrrolidine residue along with the methoxyl substituent at C-2. ${ }^{33}$ Lycorinetype compounds, which are biogenetically related to the homolycorine skeleton, also suffer a retro-Diels Alder process followed by the loss of $\mathrm{C}-1$ and $\mathrm{C}-2$, along with their substituents, yielding the base peak at $m / z 228,242$ and 


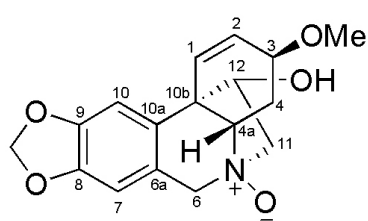

(1)<smiles>CNc1ccccc1-c1cc2c(cc1CO)OCO2</smiles>

(2)<smiles>c1ccc2c(c1)ncc1cc3c(cc12)OCO3</smiles>

(3)<smiles>[R7]C1([R2])C=C[C@@]2(C)CCN(C)Cc3ccc(OC)c(c32)O1</smiles>

(4) $\mathrm{R}_{1}=\mathrm{OH}, \mathrm{R}_{2}=\mathrm{H}$<smiles>CNCc1ccc(OC)c2c1[C@]1(C)CC[C@@H](O)C[C@@H]1O2</smiles>

(5)<smiles>CO[C@H]1C=C[C@@]2(CCN3CC[C@@H]2c2cc4c(cc2C3)OCO4)C1</smiles>

(6)<smiles>COc1cc2c(c(O)c1OC)[C@H]1CC[C@@H](OC)CN1CN2C</smiles>

(15)

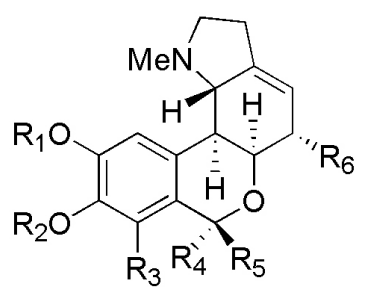

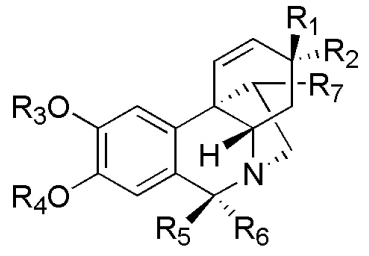

(7) $\mathrm{R}_{1}=\mathrm{OH}, \mathrm{R}_{2}=\mathrm{H}, \mathrm{R}_{3}+\mathrm{R}_{4}=\mathrm{CH}_{2}, \mathrm{R}_{5}=\mathrm{H}, \mathrm{R}_{6}=\mathrm{H}, \mathrm{R}_{7}=\mathrm{H}$ (11) $\mathrm{R}_{1}=\mathrm{OH}, \mathrm{R}_{2}=\mathrm{H}, \mathrm{R}_{3}=\mathrm{Me}, \mathrm{R}_{4}=\mathrm{H}, \mathrm{R}_{5}=\mathrm{H}, \mathrm{R}_{6}=\mathrm{H}, \mathrm{R}_{7}=\mathrm{H}$ (13) $\mathrm{R}_{1}=\mathrm{OMe}, \mathrm{R}_{2}=\mathrm{H}, \mathrm{R}_{3}+\mathrm{R}_{4}=\mathrm{CH}_{2}, \mathrm{R}_{5}=\mathrm{H}, \mathrm{R}_{6}=\mathrm{H}, \mathrm{R}_{7}=\mathrm{O}$ (16) $\mathrm{R}_{1}=\mathrm{OMe}, \mathrm{R}_{2}=\mathrm{H}, \mathrm{R}_{3}+\mathrm{R}_{4}=\mathrm{CH}_{2}, \mathrm{R}_{5}=\mathrm{H}, \mathrm{R}_{6}=\mathrm{H}, \mathrm{R}_{7}=\mathrm{OH}$ (17) $\mathrm{R}_{1}=\mathrm{H}, \mathrm{R}_{2}=\mathrm{OMe}, \mathrm{R}_{3}+\mathrm{R}_{4}=\mathrm{CH}_{2}, \mathrm{R}_{5}=\mathrm{H}, \mathrm{R}_{6}=\mathrm{H}, \mathrm{R}_{7}=\mathrm{OH}$ (20) $\mathrm{R}_{1}=\mathrm{H}, \mathrm{R}_{2}=\mathrm{OH}, \mathrm{R}_{3}+\mathrm{R}_{4}=\mathrm{CH}_{2}, \mathrm{R}_{5}=\mathrm{H}, \mathrm{R}_{6}=\mathrm{H}, \mathrm{R}_{7}=\mathrm{OH}$ (22) $\mathrm{R}_{1}=\mathrm{OMe}, \mathrm{R}_{2}=\mathrm{H}, \mathrm{R}_{3}+\mathrm{R}_{4}=\mathrm{CH}_{2}, \mathrm{R}_{5}=\mathrm{H}, \mathrm{R}_{6}=\mathrm{OH}, \mathrm{R}_{7}=\mathrm{OH}$ (23) $\mathrm{R}_{1}=\mathrm{OMe}, \mathrm{R}_{2}=\mathrm{H}, \mathrm{R}_{3}+\mathrm{R}_{4}=\mathrm{CH}_{2}, \mathrm{R}_{5}=\mathrm{OH}, \mathrm{R}_{6}=\mathrm{H}, \mathrm{R}_{7}=\mathrm{OH}$ (24) $\mathrm{R}_{1}=\mathrm{OH}, \mathrm{R}_{2}=\mathrm{H}, \mathrm{R}_{3}+\mathrm{R}_{4}=\mathrm{CH}_{2}, \mathrm{R}_{5}=\mathrm{H}, \mathrm{R}_{6}=\mathrm{H}, \mathrm{R}_{7}=\mathrm{OH}$<smiles>COc1cc2c(cc1OC)[C@@]1(C)[C@@H](O)[C@H](OC)[C@H]3O[C@]34CCN(C2)[C@@H]41</smiles>

(26)

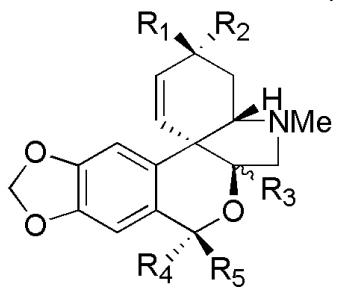

(18) $\mathrm{R}_{1}=\mathrm{OMe}, \mathrm{R}_{2}=\mathrm{H}, \mathrm{R}_{3}=\mathrm{OH}, \mathrm{R}_{4}=\mathrm{R}_{5}=\mathrm{H}$ (19) $\mathrm{R}_{1}=\mathrm{OMe}, \mathrm{R}_{2}=\mathrm{H}, \mathrm{R}_{3}=\mathrm{H} \beta, \mathrm{R}_{4}=\mathrm{H}, \mathrm{R}_{5}=\mathrm{OH}$ (28) $\mathrm{R}_{1}=\mathrm{OMe}, \mathrm{R}_{2}=\mathrm{H}, \mathrm{R}_{3}=\mathrm{H} \beta, \mathrm{R}_{4}+\mathrm{R}_{5}=\mathrm{O}$
(9) $\mathrm{R}_{1}=\mathrm{Me}, \mathrm{R}_{2}=\mathrm{Me}, \mathrm{R}_{3}=\mathrm{H}, \mathrm{R}_{4}=\mathrm{OMe}, \mathrm{R}_{5}=\mathrm{H}, \mathrm{R}_{6}=\mathrm{H}$ (10) $\mathrm{R}_{1}=\mathrm{Me}, \mathrm{R}_{2}=\mathrm{Me}, \mathrm{R}_{3}=\mathrm{OMe}, \mathrm{R}_{4}=\mathrm{OH}, \mathrm{R}_{5}=\mathrm{H}, \mathrm{R}_{6}=\mathrm{H}$ (12) $R_{1}=M e, R_{2}=M e, R_{3}=O M e, R_{4}=O M e, R_{5}=H, R_{6}=H$ (27) $\mathrm{R}_{1}=\mathrm{Me}, \mathrm{R}_{2}=\mathrm{Me}, \mathrm{R}_{3}=\mathrm{H}, \mathrm{R}_{4}+\mathrm{R}_{5}=\mathrm{O}, \mathrm{R}_{6}=\mathrm{H}$ (29) $\mathrm{R}_{1}=\mathrm{Me}, \mathrm{R}_{2}=\mathrm{Me}, \mathrm{R}_{3}=\mathrm{OMe}, \mathrm{R}_{4}+\mathrm{R}_{5}=\mathrm{O}, \mathrm{R}_{6}=\mathrm{H}$ (30) $\mathrm{R}_{1}=\mathrm{Me}, \mathrm{R}_{2}=\mathrm{H}, \mathrm{R}_{3}=\mathrm{H}, \mathrm{R}_{4}+\mathrm{R}_{5}=\mathrm{O}, \mathrm{R}_{6}=\mathrm{H}$ (31) $R_{1}=M e, R_{2}=M e, R_{3}=H, R_{4}+R_{5}=O, R_{6}=O M e$

Figure 2. Alkaloids identified in Hippeastrum aulicum.

226 for compounds 14, 21 and 25, respectively. Alkaloid 26, which lacks the 3,4-unsaturation, possesses the base peak at $m / z, 332$ (M-1) instead of the typical base peak after the retro-Diels Alder process. ${ }^{34}$

The EI-MS fragmentation of the tazettine-type skeleton, represented by compounds $\mathbf{1 8}, \mathbf{1 9}$ and 28, is strongly supported by the stereochemistry of the substituent at C-3. The $\beta$-orientation of the $\mathrm{C}$ - 3 substituent induces a retro-Diels Alder process at ring $\mathrm{C}$ followed by the loss of the neutral fragment $\left[\mathrm{C}_{5} \mathrm{H}_{8} \mathrm{O}\right]$, which yields the base peaks at $\mathrm{m} / z 247$ and 245 for compounds $\mathbf{1 8}$ and $\mathbf{2 8}$, respectively (Table 2). Compound 18 is an artefact of 19 under CGC-MS. ${ }^{31}$ Considering the high temperature of the CGC-MS method, the haemanthamine-type skeleton also suffers a thermal decomposition, particularly those compounds with a substitution at C-11, as in the case of 13, 16, 17, 20, 22, 23 and 24. ${ }^{6,35}$ Conversely, the EI-MS fragmentation of galanthamine-type compounds under CGC and direct insertion probe (DIP) conditions are very similar and feature abundant $[\mathrm{M}]^{+}$and $[\mathrm{M}-\mathrm{H}]^{+}$ion peaks, similarly to lycorine-type alkaloids. ${ }^{36}$ The galanthamine-type compounds also show typical fragmentation, with domination of one or another pathway depending on the substituents of the skeleton. In summary, the 4,4a-unsaturation induces the loss of the substituent at C-3 followed by the elimination of the nitrogen $\left[\mathrm{C}_{3} \mathrm{H}_{7} \mathrm{~N}\right]$, as in galanthamine (4) and narwedine (8). In the EI-MS spectrum of lycoramine (5), a dihydro derivative, this induction is weaker and the remaining ion peaks are considerably less abundant than those observed for galanthamine (4) and narwedine (8) (Table 2).

Phytochemical procedure and NMR data of haemanthamine $N$-oxide (1)

In the course of the phytochemical procedure, the known Amaryllidaceae alkaloids haemanthamine (16), ${ }^{19,23}$ 
albomaculine (29), ${ }^{18}$ haemanthidine (22) 6-epihaemanthidine (23), ${ }^{19}$ 7-methoxy-Omethyllycorenine (12), ${ }^{18}$ aulicine $(\mathbf{1 5}),{ }^{18}$ lycorine (25), ${ }^{22,23}$ trisphaeridine (3), ${ }^{21,24}$ galanthine (21), ${ }^{20}$ and norpluviine (14), ${ }^{25}$ were isolated and identified by comparison of their spectroscopic data with those previously reported. The phytochemical procedure was assisted by CGC-MS and the new compound haemanthamine $N$-oxide (1) was purified from a natural source for the first time. Compound $\mathbf{1}$ showed an ${ }^{1} \mathrm{H}$ NMR spectrum very similar to that of haemanthamine. The characteristic ${ }^{1} \mathrm{H}$ NMR spectrum included: (i) two paraoriented aryl singlets at $\delta 6.98$ and 6.68 , the most deshielded of which was assigned to H-10 due to its NOESY (nuclear Overhauser effect spectroscopy) correlation with H-1; (ii) $\mathrm{H}-1$ and $\mathrm{H}-2$ were assigned at $\delta 6.36(2 \mathrm{H})$, confirmed by COSY (correlation spectroscopy) correlation with H-3 $(\delta$ 4.02) and two HSQC (heteronuclear single quantum coherence) correlations at $\delta 126.8$ and 131.5 , respectively; (iii) a typical resonance at $\delta 5.97$ corresponding to the methylenedioxy group; (iv) the aliphatic methoxyl group confirmed at position C-3 due to the HMBC (heteronuclear multiple bond correlation) correlation between 3-OMe and $\mathrm{C}-3$; (v) the magnitude of the coupling constant between H- $4 \alpha$ and H-3 $(J=4.4 \mathrm{~Hz})$ was indicative of a trans relationship between 3-OMe and the 5,10b-ethano bridge. The remaining ${ }^{1} \mathrm{H}$ NMR signals were consistent with the structure of haemanthamine (16), with the exception of positions $\mathrm{H}-4 \mathrm{a}, \mathrm{H}-6$ and $\mathrm{H}-12$. The $\mathrm{H}-4 \mathrm{a}$ resonance was $0.48 \mathrm{ppm}$ more deshielded than its homolog in haemanthamine. Both H-6 were assigned at $\delta 4.68$ and $4.75 \mathrm{ppm}, 0.94$ and $0.49 \mathrm{ppm}$ more deshielded than the H- $6 \alpha$ and H-6 $6 \beta$ in haemanthamine, respectively. Finally, the $\mathrm{H}-12$ endo and $\mathrm{H}-12$ exo were 0.94 and $0.50 \mathrm{ppm}$ more deshielded than their homologs in haemanthamine. This kind of deshielding effect was congruent with the alkaloid haemanthamine in salt or $N$-oxide form. HRESIMS analysis was carried out to confirm an additional oxygen atom in the structure. Compound $\mathbf{1}$ exhibited a parent $[\mathrm{M}+\mathrm{H}]^{+}$ion at $m / z 318.13362$ in its HRESIMS spectrum, suggesting the molecular formula $\mathrm{C}_{17} \mathrm{H}_{20} \mathrm{NO}_{5}$ (calcd. 318.13360), and confirming $\mathbf{1}$ as haemanthamine $N$-oxide. Haemanthamine $N$-oxide (1) was obtained here for the first time from a natural source, even though it has already been obtained by synthesis. ${ }^{37}$ The complete 1D and 2D NMR data are shown in Table 1.

The confirmation of the absolute stereochemistry of $\mathbf{1}$ was achieved through circular dichroism (CD). Negative and positive Cotton effects were observed at 245 and $294 \mathrm{~nm}$, whose absorptions were in agreement with the haemanthamine-type skeleton. ${ }^{38}$

\section{LS(+)-MS and PS(+)-MS}

Figure 3 displays the LS(+) mass spectra for bulb and leaf analyses of $H$. aulicum, which had a similar chemical profile. Signals varying from $\mathrm{m} / \mathrm{z} 280$ to 400 were detected as protonated molecules, $[\mathrm{M}+\mathrm{H}]^{+}$. A similar $\mathrm{m} / \mathrm{z}$ distribution has been observed for Hibiscus species. ${ }^{16}$ Table 3 shows measured $m / z$ values, mass error (ppm), DBE and molecular formula of the main compounds detected by the LS(+)-MS technique, where 10 and 8 species were identified in bulb and leaf, respectively. The ions of $\mathrm{m} / \mathrm{z}, 302,318,320,332$ and 348 are the most abundant species found, having double bond equivalents (DBEs) of 7-9. These species correspond to alkaloids, presenting odd molecular weight values from molecular formula of neutral species $(\mathrm{M})$. As a consequence, an odd number of nitrogen is detected in their chemical structure, $\mathrm{N}_{1} \mathrm{O}_{\mathrm{x}}$ class, where $\mathrm{x}=4-6$ (Table 3). The species of $m / z, 302.1387$ and $320.1858\left(\left[\mathrm{C}_{17} \mathrm{H}_{19} \mathrm{NO}_{4}+\mathrm{H}\right]^{+}\right.$and $\left[\mathrm{C}_{18} \mathrm{H}_{25} \mathrm{NO}_{4}+\mathrm{H}\right]^{+}$ions $)$ correspond to haemanthamine (16) and/or its isomers and aulicine (15), respectively (Figure 1). The high relative intensity detected for these species is in good agreement with the CGC-MS data (Table 2). Compounds with $\mathrm{m} / \mathrm{z}$ 318.1337, 332.1492 and $348.1809\left(\left[\mathrm{C}_{17} \mathrm{H}_{19} \mathrm{NO}_{5}+\mathrm{H}\right]^{+}\right.$, $\left[\mathrm{C}_{18} \mathrm{H}_{21} \mathrm{NO}_{5}+\mathrm{H}\right]^{+}$and $\left[\mathrm{C}_{19} \mathrm{H}_{25} \mathrm{NO}_{5}+\mathrm{H}\right]^{+}$ions, respectively) correspond to haemanthamine $N$-oxide (1) and its isomer, tazettine/petrazettine (18-19), and nerinine (10), respectively. The first compound is an isobar of galanthine (21), $\mathrm{M}=\mathrm{C}_{18} \mathrm{H}_{23} \mathrm{NO}_{4}$, which was only detected by the CGC-MS technique (Table 2). The ion of $m / z 288.1233$, detected only in bulbs, corresponds to the $\left[\mathrm{C}_{16} \mathrm{H}_{17} \mathrm{NO}_{4}+\mathrm{H}\right]^{+}$ion, that is, lycorine (25), 11-hydroxyvittatine (24) or hamayne (20). The galanthamine (4) isobar, $\mathrm{M}=\mathrm{C}_{17} \mathrm{H}_{21} \mathrm{NO}_{3}$ and $\mathrm{M}_{\mathrm{w}} 287 \mathrm{Da}$, was not identified, as indicated in Table 2. Another alkaloid was detected from $\mathrm{LS}(+)$-MS as a $\left[\mathrm{C}_{18} \mathrm{H}_{25} \mathrm{NO}_{5}+\mathrm{H}\right]^{+}$ion of $\mathrm{m} / \mathrm{z} 336$ (Table 3), although no chemical structure has been proposed so far. The only species not classified as an alkaloid was detected by LS(+)-MS as a sugar: an adduct sucrose, $\left[\mathrm{C}_{12} \mathrm{H}_{22} \mathrm{O}_{11}+\mathrm{K}\right]^{+}$ion of $m / z 381.0801$.

Figure 4 shows PS(+)-FT-ICR mass spectra from $n$-Hex and EtOAc extracts of bulbs and leaves for H. aulicum. The chemical profiles for extracts of bulbs and leaves are quite similar. However, the PS(+) technique promotes a selective ionization for compounds of $m / z \geq 332$ for bulb extracts ( $n$-Hex and EtOAc), while in leaf extracts, two alkaloids are selectively identified: ions of $\mathrm{m} / z, 362\left(\left[\mathrm{C}_{20} \mathrm{H}_{27} \mathrm{NO}_{5}+\mathrm{H}\right]^{+}\right)$, and $376\left(\left[\mathrm{C}_{20} \mathrm{H}_{25} \mathrm{NO}_{6}+\mathrm{H}\right]^{+}\right)$. Among them, the ion of $m / z 362$ (7-methoxy- $O$-methyllycorenine (12)) is also listed in Table 2. Figures $5 \mathrm{a}$ and $5 \mathrm{~b}$ compare the relative intensity of most ions detected $(\mathrm{m} / \mathrm{z}, 288,302,316,318,320,332,336$, $346,348,356,374,376,362$ and 381$)$ by both LS(+)-MS 


\section{LS(+)-FT-ICR MS \\ Bulb}

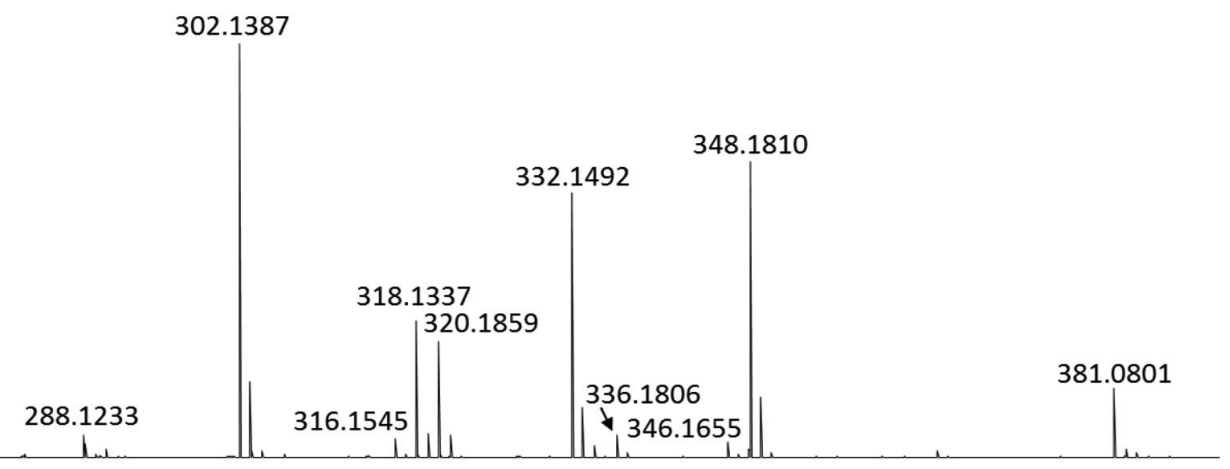

\section{LS(+)-FT-ICR MS \\ Leaf}

\subsection{7}

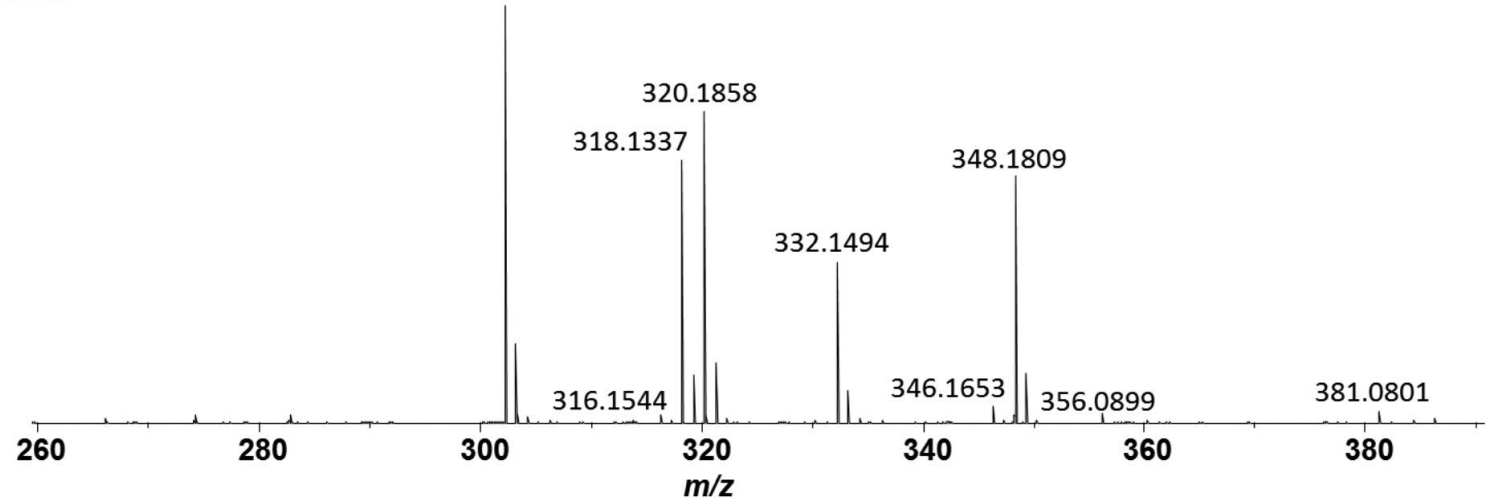

Figure 3. LS(+)-FT-ICR mass spectra for bulb and leaf analysis of H. aulicum.

Table 3. Measured $\mathrm{m} / \mathrm{z}$ values, mass error (ppm), DBE and molecular formula of main compounds detected from LS(+)-MS and PS(+)-MS data for $H$. aulicum

\begin{tabular}{|c|c|c|c|c|c|c|c|c|c|c|}
\hline \multirow{3}{*}{ Proposed alkaloid } & \multicolumn{2}{|c|}{ LS-MS $^{\text {a }}$} & \multicolumn{4}{|c|}{ PS-MS } & \multirow{3}{*}{$m / z_{\text {measured }}$} & \multirow{3}{*}{ Error / ppm } & \multirow{3}{*}{$\mathrm{DBE}^{\mathrm{e}}$} & \multirow{3}{*}[\mathrm{M}+\mathrm{H}]{$^{+}$} \\
\hline & \multirow{2}{*}{ Bulb } & \multirow{2}{*}{ Leaf } & \multicolumn{2}{|c|}{ Bulbs $^{\mathrm{c}}$} & \multicolumn{2}{|c|}{ Leaves $^{\mathrm{d}}$} & & & & \\
\hline & & & IB & IIB & IA & IIA & & & & \\
\hline $\begin{array}{l}\text { Hamayne (20) or 11-hydroxyvittatine (24) } \\
\text { or lycorine (25) }\end{array}$ & $\mathrm{X}$ & - & - & $\mathrm{X}$ & - & - & 288.12288 & 0.55 & 9 & {$\left[\mathrm{C}_{16} \mathrm{H}_{17} \mathrm{NO}_{4}+\mathrm{H}\right]^{+}$} \\
\hline $\begin{array}{l}\text { Haemanthamine }(\mathbf{1 6}) \text { or crinamine }(\mathbf{1 7}) \\
\text { or } 8 \text { - } O \text {-demethylhomolycorine }(\mathbf{3 0})\end{array}$ & $\mathrm{X}$ & $\mathrm{X}$ & $\mathrm{X}$ & $\mathrm{X}$ & $\mathrm{X}$ & $\mathrm{X}$ & 302.13868 & 0.02 & 9 & {$\left[\mathrm{C}_{17} \mathrm{H}_{19} \mathrm{NO}_{4}+\mathrm{H}\right]^{+}$} \\
\hline Homolycorine (27) & $\mathrm{X}$ & $\mathrm{X}$ & - & - & - & - & 316.15443 & 0.30 & 9 & {$\left[\mathrm{C}_{18} \mathrm{H}_{21} \mathrm{NO}_{4}+\mathrm{H}\right]^{+}$} \\
\hline \multirow{2}{*}{$\begin{array}{l}\text { Haemanthidine (22) or 6-epihaemanthidine (23) } \\
\text { or haemanthamine } N \text {-oxide (1) }\end{array}$} & $\mathrm{X}$ & $\mathrm{X}$ & $\mathrm{X}$ & $\mathrm{X}$ & - & $\mathrm{X}$ & 318.13369 & 0.29 & 9 & {$\left[\mathrm{C}_{17} \mathrm{H}_{19} \mathrm{NO}_{5}+\mathrm{H}\right]^{+}$} \\
\hline & - & $\mathrm{X}$ & - & - & - & - & 356.08986 & 1.06 & & {$\left[\mathrm{C}_{17} \mathrm{H}_{19} \mathrm{NO}_{5}+\mathrm{K}\right]^{+}$} \\
\hline Aulicine (15) & $\mathrm{X}$ & $\mathrm{X}$ & $\mathrm{X}$ & $\mathrm{X}$ & $\mathrm{X}$ & $\mathrm{X}$ & 320.18577 & 0.42 & 7 & {$\left[\mathrm{C}_{18} \mathrm{H}_{25} \mathrm{NO}_{4}+\mathrm{H}\right]^{+}$} \\
\hline Tazettine (18) or pretazettine (19) & $\mathrm{X}$ & $\mathrm{X}$ & $\mathrm{X}$ & $\mathrm{X}$ & - & $\mathrm{X}$ & 332.14924 & 0.03 & 9 & {$\left[\mathrm{C}_{18} \mathrm{H}_{21} \mathrm{NO}_{5}+\mathrm{H}\right]^{+}$} \\
\hline- & $\mathrm{X}$ & - & $\mathrm{X}$ & $\mathrm{X}$ & $\mathrm{X}$ & $\mathrm{X}$ & 336.18058 & 0.08 & 7 & {$\left[\mathrm{C}_{18} \mathrm{H}_{25} \mathrm{NO}_{5}+\mathrm{H}\right]^{+}$} \\
\hline 2 $\alpha$-Methoxyhomolycorine (31) & $\mathrm{X}$ & $\mathrm{X}$ & $\mathrm{X}$ & - & - & $\mathrm{X}$ & 346.16562 & 0.72 & 9 & {$\left[\mathrm{C}_{19} \mathrm{H}_{23} \mathrm{NO}_{5}+\mathrm{H}\right]$} \\
\hline Nerinine (10) & $\mathrm{X}$ & $\mathrm{X}$ & $\mathrm{X}$ & $\mathrm{X}$ & $\mathrm{X}$ & $\mathrm{X}$ & 348.18086 & 0.91 & 8 & {$\left[\mathrm{C}_{19} \mathrm{H}_{25} \mathrm{NO}_{5}+\mathrm{H}\right]^{+}$} \\
\hline 7-Methoxy- $O$-methyllycorenine (12) & - & - & $\mathrm{X}$ & $\mathrm{X}$ & $\mathrm{X}$ & $\mathrm{X}$ & 362.19673 & 1.46 & 8 & {$\left[\mathrm{C}_{20} \mathrm{H}_{27} \mathrm{NO}_{5}+\mathrm{H}\right]^{+}$} \\
\hline- & - & - & - & $\mathrm{X}$ & $\mathrm{X}$ & - & 376.17629 & 2.19 & 9 & {$\left[\mathrm{C}_{20} \mathrm{H}_{25} \mathrm{NO}_{6}+\mathrm{H}\right]^{+}$} \\
\hline Sucrose or isomers & $\mathrm{X}$ & $\mathrm{X}$ & - & - & - & - & 381.08008 & 1.86 & 2 & {$\left[\mathrm{C}_{12} \mathrm{H}_{22} \mathrm{O}_{11}+\mathrm{K}\right]^{+}$} \\
\hline
\end{tabular}

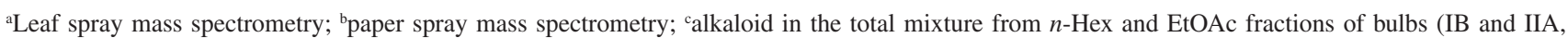
respectively); ${ }^{\mathrm{d} a l k a l o i d}$ in the total mixture from $n$-Hex and EtOAc fractions of leaves (IA and IIA, respectively); ${ }^{\mathrm{e}}$ double bond equivalent. 
(Figure 5a) and PS(+)-MS (Figure 5b). In general, a good agreement is observed between the ambient MS techniques. LS(+)-MS has proved to be a promising approach for the identification of alkaloids from Hippeastrum aulicum (Ker Gawl.) Herb. and should be explored in future work with other species, since it is a fast and easy analysis requiring no prior step of sample preparation.

\section{Conclusions}

The phytochemical investigation of Hippeastrum aulicum resulted in the identification of thirty-one alkaloids and the CGC-MS dereplication proved to be very useful for the fast identification of a great number of compounds from an alkaloid-rich $H$. aulicum extract. The phytochemical fractionation assisted by CGC-MS analysis allowed the isolation of the new compound haemanthamine $N$-oxide (1), reported for the first time from a natural source.

Paper and leaf spray ionization mass spectrometry constitute a new family of ionization techniques able to identify alkaloids directly from their natural environments, i.e., in the "real world" of analytes (as demonstrated by LS-MS) or when placed on auxiliary surfaces such as PSMS. A total of 13 species were identified with $\mathrm{m} / \mathrm{z}$, ranging

\section{PS(+)-FT-ICR MS} $n$-Hex extract of bulbs

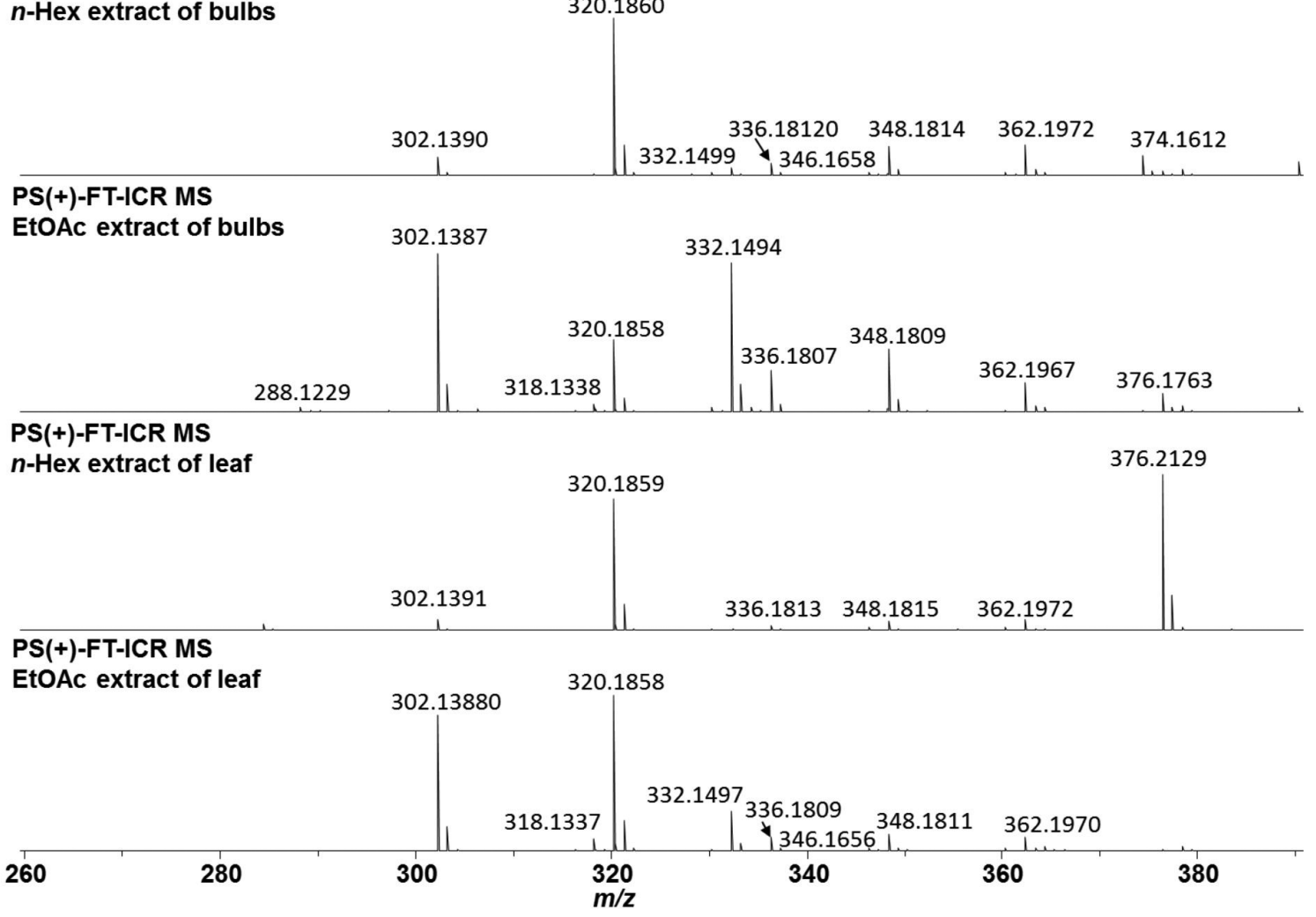

Figure 4. PS(+)-FT-ICR mass spectra from $n$-Hex and EtOAc extracts of bulbs and leaves for H. aulicum.

(a) LS-MS

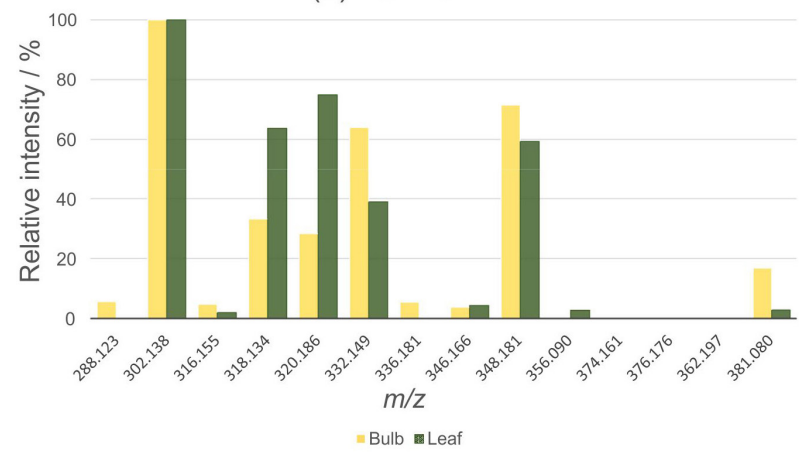

(b) PS-MS

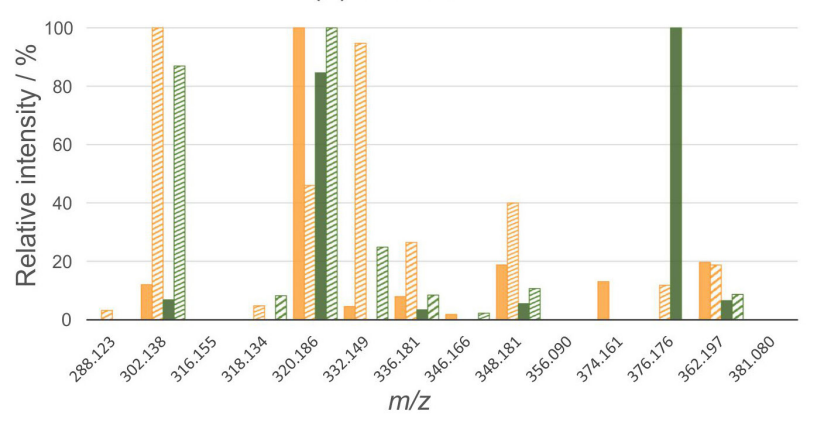

$\equiv n$-Hex fractions of bulbs $\square$ EtOAc fractions of bulbs $₫ \mathrm{n}$-Hex fractions of leafs $\square$ EtOAc fractions of leafs

Figure 5. Comparison of relative intensity of main ions detected from LS(+) and PS(+)-FT-ICR MS of bulbs and leaves for H. aulicum. 
from 200 to 400, DBEs of 7-10 and exact mass lower than $2 \mathrm{ppm}$. Regarding the chemical structure of alkaloids, their carbon number varied from $\mathrm{C}_{16}$ to $\mathrm{C}_{20}$, containing $\mathrm{NO}_{x}$ as the heteroatom class, where $\mathrm{x}=4-6$. Among the main species detected were compounds with $\mathrm{m} / \mathrm{z}, 302,318,320,332$ and 348 , which correspond to haemanthamine (16) and/or its isomers (17 and 30), haemanthamine $N$-oxide (1) and its isomers (22 and 23), aulicine (15), tazettine/pretazettine (18 and 19), and nerinine (10), respectively. Similar LS(+)-MS and PS(+)-MS results were obtained from leaf and bulb surfaces. Taken together, the results obtained from ambient ionization MS demonstrated a notable agreement with the CGC-MS analysis.

\section{Supplementary Information}

Spectra and NMR data of all isolated alkaloids are available free of charge at http://jbcs.sbq.org.br.

\section{Acknowledgments}

The authors thank R. P. Camargo for collecting the plant material. The authors also thank CAPES-PVE (No. 88881.030427/2013-01), CNPq (445987/2014-6), CAPES (23038.007083/2014-40), FAPES (65921380/2013) and NCQP-UFES.

\section{References}

1. Bastida, J.; Berkov, S.; Torras-Claveria, L.; Pigni, N. B.; de Andrade, J. P.; Martínez, V.; Codina, C.; Viladomat, F. In Recent Advances in Pharmaceutical Sciences; Muñoz-Torrero, D., ed.; Transworld Research Network: Kerala, 2011.

2. Cortes, N.; Alvarez, R.; Osorio, E. H.; Alzate, F.; Berkov, S.; Osorio, E.; J. Pharm. Biomed. Anal. 2015, 102, 222.

3. Shawky, E.; Abou-Donia, A. H.; Darwish, F. A.; Toaima, S. M.; Takla, S. S.; Pigni, N. B.; Bastida, J.; Chem. Biodiversity 2015, 12,1184

4. Hubert, J.; Nuzillard, J.-M.; Renault, J.-H.; Phytochem. Rev. 2015, DOI 10.1007/s11101-015-9448-7.

5. Berkov, S.; Bastida, J.; Sidjimova, B.; Viladomat, F.; Codina, C.; Chem. Biodiversity 2011, 8, 115.

6. Kreh, M.; Matusch, R.; Witte, L.; Phytochemistry 1995, 38, 773.

7. Alberici, R. M.; Simas, R. C.; Sanvido, G. B.; Romão, W.; Lalli, P. M.; Benassi, M.; Cunha, I. B. S.; Eberlin, M. N.; Anal. Bioanal. Chem. 2010, 398, 265.

8. Harris, G. A.; Galhena, S.; Fernández, F. M.; Anal. Chem. 2011, 83,4508 .

9. Pereira, I.; Rodrigues, S. R. M.; Carvalho, T. C.; Carvalho, V. V.; Sanz Lobon, G.; Bassane, J. F.; Domingos, E.; Romão, W.; Augusti, R.; Vaz, B. G.; Anal. Methods 2016, 8, 6023.
10. Klampfl, C. W.; Himmelsbach, M.; Anal. Chim. Acta 2015, 890, 44.

11. Snyder, D. T.; Schilling, M. C.; Hochwender, C. G.; Kaufman, A. D.; Anal. Methods 2015, 7, 870 .

12. Garrett, R.; Rezende, C. M.; Ifa, D. R.; Anal. Methods 2013, 5, 5944.

13. Soparawalla, S.; Tadjimukhamedov, F. K.; Wiley, J. S.; Ouyang, Z.; Cooks, R. G.; Analyst 2011, 136, 4392.

14. Mazzotti, F.; di Donna, L.; Taverna, D.; Nardi, M.; Aiello, D.; Napoli, A.; Sindona, G.; Int. J. Mass Spectrom. 2013, 352, 87.

15. Deng, J.; Yang, Y.; Anal. Chim. Acta 2013, 785, 82.

16. Muller, T.; Cooks, R. G.; Bull. Korean Chem. Soc. 2014, 35, 919.

17. Schrage, M.; Shen, Y.; Claassen, F. W.; Zuilhof, H.; Nielen, M. W.; Chen, B.; van Beek, T. A.; J. Chromatogr. A 2013, 1317, 246.

18. de Andrade, J. P.; Guo, Y.; Font-Bardia, M.; Calvet, T.; Dutilh, J.; Viladomat, F.; Codina, C.; Nair, J. J.; Zuanazzi, J. A. S.; Bastida, J.; Phytochemistry 2014, 103, 188.

19. Pabuççuaglu, V.; Richomme, P.; Gözler, T.; Kivçak, B.; Freyer, A. J.; Shamma, M.; J. Nat. Prod. 1989, 52, 785.

20. Bastida, J.; Codina, C.; Viladomat, F.; Rubiralta, M.; Quirion, J. C.; Husson, H. P.; Ma, G. E.; J. Nat. Prod. 1990, 53, 1456.

21. Suau, R.; Gomez, A. I.; Rico, R.; Phytochemistry 1990, 29 , 1710.

22. Likhitwitayawuid, K.; Angerhofer, C. K.; Chai, H.; Pezzuto, J. M.; Cordell, G. A.; Ruangrungsi, N.; J. Nat. Prod. 1993, 56, 1331.

23. Bastida, J.; Lavilla, R.; Viladomat, F. In The Alkaloids; Cordell, G. A., ed.; Elsevier: Amsterdam, 2006, p. 87.

24. Portela-Cubillo, F.; Scott, J. S.; Walton, J. C.; J. Org. Chem. 2008, 73, 5558.

25. Lamoral-Theys, D.; Andolfi, A.; Van Goietsenoven, G.; Cimmino, A.; Le Calvé, B.; Wauthoz, N.; Mégalizzi, V.; Gras, T.; Bruyère, C.; Dubois, J.; Mathieu, V.; Kornienko, A.; Kiss, R.; Evidente, A.; J. Med. Chem. 2009, 52, 6244.

26. Osorio, E. J.; Berkov, S.; Brun, R.; Codina, C.; Viladomat, F.; Cabezas, F.; Bastida, J.; Phytochem. Lett. 2010, 3, 161.

27. Carvalho, T. C.; Oliveira, I. F.; Tose, L. V.; Vanini, G.; Kill, J. B.; Neto, A. C.; Machado, L. F.; Laboissiere, J. C.; Junior, V. L.; Vaz, B. G.; Romão, W.; Anal. Methods 2016, 8, 614.

28. Colletes, T. C.; Garcia, P. T.; Campanha, R. B.; Abdelnur, P. V.; Romão, W.; Coltro, W. K. T.; Vaz, B. G.; Analyst 2016, 141, 1707.

29. Oliveira, B. G.; Costa, H. B.; Ventura, J. A.; Kondratyuk, T. P.; Barroso, M. E. S.; Correia, R. M.; Pimentel, E. F.; Pinto, F. E.; Endringer, D. C.; Romão, W.; Food Chem. 2016, 204, 37.

30. Boit, H. G.; Döpke, W.; Naturwissenschaften 1960, 47, 109.

31. de Andrade, J. P.; Pigni, N. B.; Torras-Claveria, L.; Berkov, S.; Codina, C.; Viladomat, F.; Bastida, J.; J. Pharm. Biomed. Anal. 2012, 70, 13 . 
32. de Andrade, J. P.; Pigni, N. B.; Torras-Claveria, L.; Guo, Y.; Berkov, S.; Reyes-Chilpa, R.; El Amrani, A.; Zuanazzi, J. A. S.; Codina, C.; Viladomat, F.; Bastida, J.; Rev. Latinoam. Quim. 2012, 40, 83 .

33. Ibuka, T.; Irie, H.; Kato, A.; Uyeo, S.; Tetrahedron Lett. 1966, 39,4745 .

34. Kinstle, T. H.; Wildman, W. C.; Brown, C. L.; Tetrahedron Lett. 1966, 39, 4659.

35. Duffield, A. M.; Aplin, R. T.; Budzikiewicz, H.; Djerassi, C.; Murphy, C. F.; Wildman, W. C.; J. Am. Chem. Soc. 1965, 87, 4902.
36. Berkov, S.; Viladomat, F.; Codina, C.; Suárez, S.; Ravelo, A.; Bastida, J.; J. Mass Spectrom. 2012, 47, 1065.

37. Cédron, J. C.; Gutiérrez, D.; Flores, N.; Ravelo, A. G.; EstévezBraun, A.; Bioorg. Med. Chem. 2012, 20, 5464.

38. De Angelis, G. G.; Wildman, W. C.; Tetrahedron 1969, 25, 5099.

Submitted: May 5, 2016

Published online: August 12, 2016

FAPESP has sponsored the publication of this article. 